\section{Prestorage Application of Oxalic Acid to Alleviate Chilling Injury in Mango Fruit}

\author{
Peiyan Li and Xiaolin Zheng ${ }^{1}$ \\ College of Food Science and Biotechnology, Zhejiang Gongshang University, \\ Hangzhou 310018, People's Republic of China
}

Md. Golam Ferdous Chowdhury, Kim Cordasco, and Jeffrey K. Brecht ${ }^{1}$ Horticultural Sciences Department, Institute of Food and Agricultural Sciences, University of Florida, Gainesville, FL 32611-0690

Additional index words. Mangifera indica, antioxidant activity, energy metabolism, membrane integrity, free radical

\begin{abstract}
Effects of postharvest oxalic acid (OA) application on chilling injury (CI) in harvested mango fruit (Mangifera indica L.) were investigated using 'Tommy Atkins' fruit from Florida and 'Zill' fruit from Panzhihua. The $\mathrm{OA}$ was applied to harvested fruit as a 5 or $10 \mathrm{~mm}$ drench for 10 or 15 minutes at $25{ }^{\circ} \mathrm{C}$. 'Tommy Atkins' fruit typically develop external CI symptoms while 'Zill' develops internal symptoms. Development of CI symptoms was significantly reduced in OA-treated 'Tommy Atkins' fruit stored for 18 days at $5^{\circ} \mathrm{C}$ as was the rate of softening upon transfer to $25^{\circ} \mathrm{C}$ for 4 days. However, $\mathrm{OA}$ treatment did not substantially control fruit decay. For 'Zill', CI development was significantly reduced in $\mathrm{OA}$-treated fruit during storage at $10{ }^{\circ} \mathrm{C}$ for 49 days and subsequently for 4 days at $25^{\circ} \mathrm{C}$. In addition, membrane integrity was enhanced and the activities of the antioxidant system enzymes superoxide dismutase (SOD), catalase (CAT), ascorbate peroxidase (APX), and glutathione reductase (GR) were elevated, although there were decreases in both hydrogen peroxide $\left(\mathrm{H}_{2} \mathrm{O}_{2}\right)$ content and superoxide radical production in OA-treated fruit. The activities of some enzymes of the energy cycle were also elevated in the OA-treated fruit, including succinate dehydrogenase (SDH), cytochrome $\mathrm{C}$ oxidase (CCO), $\mathrm{H}^{+}$-adenosine triphosphatase $\left(\mathrm{H}^{+}\right.$-ATPase), and $\mathrm{Ca}^{2+}$ adenosine triphosphatase ( $\mathrm{Ca}^{2+}$-ATPase). Thus, $\mathrm{OA}$ may enhance $\mathrm{CI}$ tolerance in mango fruit by maintaining membrane integrity associated with enhanced antioxidant activity and regulation of energy metabolism. Application of $5 \mathrm{~mm} O A$ appears to be beneficial in controlling postharvest $\mathrm{CI}$ in mango fruit.
\end{abstract}

Mango (Mangifera indica L.) is a tropical fruit that is susceptible to CI when stored at low temperature (below $13{ }^{\circ} \mathrm{C}$ ) after harvest, which decreases fruit quality and storage life, and in turn reduces consumer acceptance (Phakawatmongkola et al., 2004). Typical CI symptoms may include unusual increase in firmness, external and internal tissue browning, poor aroma and flavor, surface pitting, uneven ripening, and increased susceptibility to postharvest rot. These symptoms may occur alone or collectively during storage at low temperature or upon transfer to room temperature (Nunes et al., 2007; Wang, 1993). Application of chemical substances such as salicylic acid (Ding et al., 2007;

Received for publication 18 Aug. 2015. Accepted for publication 2 Nov. 2015.

We acknowledge the financial support provided by the National High Technology Research and Development Program of China (No. 2012AA101607), the State Scholarship Fund for Overseas Study Program of China (No. 201308330020), and the University of Florida Agricultural Experiment Station.

${ }^{1}$ Corresponding author. E-mail: zheng9393@ 163.com; jkbrecht@ufl.edu.
Junmatong et al., 2012), methyl jasmonate (González-Aguilar et al., 2001; Junmatong et al., 2012), 2,4-dichlorophenoxyacetic acid (Wang et al., 2008), and nitric oxide fumigation (Zaharah and Singh, 2011) has contributed to alleviation of $\mathrm{CI}$ for postharvest mango fruit. Moreover, hot water treatment (HWT), which is widely applied for insect and decay control in postharvest mangoes (Anwar and Malik, 2007), also reduces CI in cold-stored mangoes (Nair et al., 2001). Although HWT may have a negative impact on the quality of mangoes, as a quarantine method its use is enforced by importing countries such as the United States for mangoes from countries in which fruit flies are present (Kim et al., 2007, 2009). Since it is applied to $>95 \%$ of the mangoes sold in the U.S. market (National Mango Board, personal communication), the HWT prescribed by U.S. Department of Agriculture-Animal and Plant Health Inspection Service (Schedule T102-a; USDA-APHIS, 2014) was applied to the fruit used in the Florida experiment in this study.

$\mathrm{OA}$ is a natural organic acid that is found ubiquitously in plant species. Prestorage OA application for fruits and vegetables has received attention due to its important roles in controlling browning, retarding ripening processes, and reducing decay incidence (Ruíz-Jiménez et al., 2014; Valero et al., 2011; Yoruk et al., 2004; Zheng and Tian, 2006; Zheng et al., 2007a, 2007b, 2012). Recently, increasing evidence has been reported that OA treatment can alleviate $\mathrm{CI}$ in chilling-sensitive fruits such as mango, pomegranate, and peach through different mechanisms (Ding et al., 2007; Jin et al., 2014; Sayyari et al., 2010). We have also reported that $\mathrm{OA}$ reduces $\mathrm{CI}$ in cv. Zill mango fruit stored at $10^{\circ} \mathrm{C}$, which we partly attribute to the modulation of proline metabolism and maintenance of high adenosine triphosphate (ATP) level and energy charge in the flesh during storage ( $\mathrm{Li}$ et al., 2014). To better understand OA application for alleviating CI in harvested mangoes, the effect of OA on mangoes with or without quarantine hot water treatment (QHWT) under chilling stress was further investigated in this study.

\section{Materials and Methods}

\section{Fruit and treatment}

Expt. 1. Mature green mango fruit (Mangifera indica L.) cv. Tommy Atkins were harvested from an orchard at the University of Florida Tropical Research and Education Center in Homestead, FL, in June 2014. The harvested fruit were transported immediately by air-conditioned car to the University of Florida Postharvest Horticulture Laboratory in Gainesville $(\approx 6 \mathrm{~h})$. Upon arrival, the fruit were held overnight in a controlled temperature room at $15{ }^{\circ} \mathrm{C}\left( \pm 0.1{ }^{\circ} \mathrm{C}\right)$ with $90 \%$ to $95 \%$ relative humidity $(\mathrm{RH})$, and then were sorted for uniformity of size and appearance, and the blemished and diseased fruit were discarded. The fruit received QHWT $\left(46.1^{\circ} \mathrm{C}\right.$ for $75 \mathrm{~min}$ ) according to USDA-APHIS protocol using a laboratory HWT system (Model HWH-2; Gaffney Engineering, Gainesville, FL) and were cooled for $10 \mathrm{~min}$ starting immediately after the QHWT using water maintained at $24^{\circ} \mathrm{C}$. Thirty fruit per treatment were then dipped in 0 (control), 5 (OA1), or $10 \mathrm{~mm} \mathrm{OA} \mathrm{(OA2)} \mathrm{solution} \mathrm{for}$ $15 \mathrm{~min}$ at $25^{\circ} \mathrm{C}$, air-dried, and stored at $5{ }^{\circ} \mathrm{C}$ $\left( \pm 0.1{ }^{\circ} \mathrm{C}\right)$ and $90 \% \mathrm{RH}$ for $18 \mathrm{~d}$, and then transferred to $25{ }^{\circ} \mathrm{C}\left( \pm 0.1{ }^{\circ} \mathrm{C}\right)$ and $85 \% \mathrm{RH}$ for $4 \mathrm{~d}$ without fruit touching. External $\mathrm{CI}$ index and fruit firmness (described below) were assessed at 3-d intervals during cold storage, whereas internal CI symptoms and fruit decay were assessed after 2 and $4 \mathrm{~d}$ at $25^{\circ} \mathrm{C}$.

Expt. 2. Mango fruit cv. Zill were harvested at $\approx 80 \%$ mature stage (Zheng et al., 2007a) from a commercial orchard in Panzhihua, China, in July 2012. Harvested fruit with uniform shape and color and without mechanical damage were selected and randomly divided into two groups. One group was dipped in $5 \mathrm{~mm}$ OA solution at room temperature for $10 \mathrm{~min}$, and the other was dipped in water (as control), and then all fruit were air-dried for $\approx 3 \mathrm{~h}$. About $15 \mathrm{~kg}$ of control and treated fruit were placed in separate cartons after each fruit was wrapped 
with a soft absorbent paper. Transit time by air from harvest to the Postharvest Laboratory at Zhejiang Gongshang University in Hangzhou city was $\approx 24 \mathrm{~h}$. Upon arrival at the laboratory, 30 fruit without injury for each treatment and sampling time were placed inside clean plastic boxes with fruit touching, and each box was enclosed in a $0.02-\mathrm{mm}$ thick polyethylene bag and held in lowtemperature chambers (MIR-554; Sanyo, Oizumi, Japan $)$ at $10{ }^{\circ} \mathrm{C}\left( \pm 0.5{ }^{\circ} \mathrm{C}\right)$ and $90 \%$ $\mathrm{RH}$ for $49 \mathrm{~d}$; the fruit were subsequently transferred to $25^{\circ} \mathrm{C}$ for $4 \mathrm{~d}$ to simulate shelf life conditions. Analysis in triplicate of 10 fruit each was undertaken at 7-d intervals during cold storage.

Determinations of external and internal CI index, fruit firmness index, and fruit decay. There were five classes used for rating the surface area affected by external CI symptoms such as greyish scald, pitting, discolored lenticels, and lesions. 0: no visible symptoms; 1: trace, symptoms $<10 \% ; 2$ : slight, symptoms from $10 \%$ to $<25 \% ; 3$ : moderate, symptoms from $25 \%$ to $<50 \%$; 4: severe, symptoms $\geq 50 \%$. External CI index was calculated using the following formula: $\sum$ (chilling scale $\times$ number of fruit in each class)/number of total fruit.

There were another five classes used for rating surface decay and internal CI damage visible upon cutting fruit in half lengthwise. 0 : no visible damage; 1 : trace, decay or damage $<0.5 \mathrm{~cm}$ diameter; 2 : slight, decay or damage from 0.5 to $<2.5 \mathrm{~cm}$ diameter; 3 : moderate, decay or damage from 2.5 to $<5.0 \mathrm{~cm}$ diameter; 4 : severe, decay or damage $\geq 5.0 \mathrm{~cm}$ diameter. Decay and internal CI damage indices were calculated using the following formula: $\sum$ (damage scale $\times$ number of fruit in each class)/number of total fruit.

Fruit firmness was assessed by hand pressure and scored using a firmness scale as follows: 5 : hard; 4: sprung; 3 : slightly soft; 2: eating soft; 1 : overly soft.

The total percentage of fruit without market value was defined as fruit decay.

Determinations of malondialdehyde and relative electrolyte leakage rate. Mesocarp tissue $(1.0 \mathrm{~g})$ was homogenized with $5.0 \mathrm{~mL}$ of $100 \mathrm{~g} \cdot \mathrm{L}^{-1}$ trichloroacetic acid, and then centrifuged at $10,000 \times g_{n}$ for $20 \mathrm{~min}$ at $4{ }^{\circ} \mathrm{C}$. The malondialdehyde (MDA) content was assayed according to the method described by Hodges et al. (1999). The MDA content was expressed on a fresh weight basis $\left(\mathrm{nmol} \cdot \mathrm{g}^{-1}\right)$.

Relative electrolyte leakage rate was determined according to the method of Zheng et al. (2007). Ten discs ( 3 to $4 \mathrm{~mm}$ thickness $\times$ $10 \mathrm{~mm}$ diameter) excised from the equatorial region of 10 fruit were rinsed and immersed into $30 \mathrm{~mL}$ of distilled water for $4 \mathrm{~h}$, and then an initial conductivity was determined with a conductivity meter (DDS-11A; Yoke Instrument, Shanghai, China). Each sample was then boiled for $15 \mathrm{~min}$, and a final conductivity measurement was taken. Relative electrolyte leakage rate was defined as relative conductivity (the initial conductivity of tissue solution/the final conductivity).
Determinations of $\mathrm{O}_{2}-$ and $\mathrm{H}_{2} \mathrm{O}_{2}$. Superoxide radical $\left(\mathrm{O}_{2}-\right.$.) production was determined according to the method of Wang and Lou (1990). Mesocarp tissue (5.0 g) was homogenized with $5.0 \mathrm{~mL}$ of $50 \mathrm{~mm}$ sodium phosphate buffer ( $\mathrm{pH} 7.8$ ) containing $1 \mathrm{~mm}$ ethylenediaminetetraacetic acid sodium (EDTA), $0.3 \%$ Triton-X, and 2\% polyvinyl polypyrrolidone (PVPP), and then centrifuged at $12,000 \times g_{\mathrm{n}}$ for $20 \mathrm{~min}$ at $4{ }^{\circ} \mathrm{C}$. The supernatant was used for testing the rate of $\mathrm{O}_{2}-$. production. A $1.0 \mathrm{~mL}$ aliquot of supernatant was mixed with $1.0 \mathrm{~mL}$ of $1 \mathrm{~mm}$ hydroxylammonium chloride, and then incubated for $60 \mathrm{~min}$ at $25^{\circ} \mathrm{C}$. The incubated solution was then added to $1.0 \mathrm{~mL}$ of $17 \mathrm{~mm}$ 3-aminobenzenesulfonic acid (SigmaAldrich, Saint Louis, MO) and $1.0 \mathrm{~mL}$ of $7 \mathrm{~mm}$ 1-naphthylamine (Sigma-Aldrich), and then further incubated for $20 \mathrm{~min}$ at $25{ }^{\circ} \mathrm{C}$. The absorbance of the solution was monitored at $530 \mathrm{~nm}$ and $\mathrm{O}_{2}-$. production was expressed as $\mathrm{nmol} \cdot \mathrm{mg}^{-1}$ prot $\cdot \mathrm{h}^{-1}$.

Mesocarp tissue $(1.0 \mathrm{~g})$ was ground with $9.0 \mathrm{~mL}$ of sodium phosphate buffer $(100 \mathrm{~mm}$, $\mathrm{pH}$ 7.8) using a mortar and pestle on ice, and then centrifuged at $10,000 \times g_{\mathrm{n}}$ for $10 \mathrm{~min}$ at $4{ }^{\circ} \mathrm{C}$. The extract was used for measuring the content of $\mathrm{H}_{2} \mathrm{O}_{2}$. The $\mathrm{H}_{2} \mathrm{O}_{2}$ content was determined using a $\mathrm{H}_{2} \mathrm{O}_{2}$ Detection Kit following the manufacturer's instructions [Nanjing Jiancheng Bioengineering Institute (NJBI), Nanjing, China]. The absorbance of the reaction mixture was monitored at $405 \mathrm{~nm}$ and the $\mathrm{H}_{2} \mathrm{O}_{2}$ content was expressed on a fresh weight basis $\left(\mu \mathrm{mol} \cdot \mathrm{g}^{-1}\right)$.

Determination of the activities of antioxidant enzymes. Mesocarp tissue samples ( $5.0 \mathrm{~g}$ taken from $\approx 1$ to $5 \mathrm{~mm}$ deep under the peel at the equatorial region) from 10 fruit for each treatment were ground in different buffers, all containing 1\% PVPP (SigmaAldrich) to measure different enzymes: $30 \mathrm{~mL}$ of sodium phosphate buffer (100 mM, $\mathrm{pH} 7.8)$ was used for SOD, CAT, and GR; and $20 \mathrm{~mL}$ of sodium phosphate buffer $(100 \mathrm{~mm}$, pH 7.0, containing 1 mм EDTA) was used for APX. Each sample was homogenized with a Kinematica tissue homogenizer (Kinematica PT 2100; Kinematica, Luzern, Switzerland) and centrifuged at $20,000 \times g_{n}$ for $30 \mathrm{~min}$. The supernatants were used as enzyme extracts for assaying enzymatic activities. All steps in the preparation of extracts were carried out at $4{ }^{\circ} \mathrm{C}$.

The SOD activity was determined as described by Madamanchi and Alscher (1991). The $3.0 \mathrm{~mL}$ of reaction mixture contained $1.7 \mathrm{~mL}$ of $50 \mathrm{~mm}$ sodium phosphate buffer, pH 7.8, $0.3 \mathrm{~mL}$ of $13 \mathrm{~mm}$ methionine, $0.3 \mathrm{~mL}$ of $10 \mu \mathrm{M}$ EDTA, $0.3 \mathrm{~mL}$ of $75 \mu \mathrm{M}$ nitro blue tetrazolium (NBT), $0.3 \mathrm{~mL}$ of $2 \mu \mathrm{M}$ riboflavin, and $0.1 \mathrm{~mL}$ of enzyme extract. The formation of blue formazan was monitored by absorbance at $560 \mathrm{~nm}$. One unit of SOD was the amount of extract that gave a $50 \%$ inhibition of the rate of reduction of NBT. The SOD activity was expressed as $\mathrm{U} \cdot \mathrm{mg}^{-1}$ prot.

The CAT activity was assayed according to the method of Beers and Sizer (1952) with minor modifications. The $3.0 \mathrm{~mL}$ of reaction mixture consisted of $2.9 \mathrm{~mL}$ of $20 \mathrm{mM} \mathrm{H}_{2} \mathrm{O}_{2}$ solution and $0.1 \mathrm{~mL}$ of enzyme extract. The decomposition of $\mathrm{H}_{2} \mathrm{O}_{2}$ was assayed by decline in absorbance at $240 \mathrm{~nm}$. One unit of CAT activity was defined as the amount of enzyme causing a decrease of 0.01 in absorbance per minute at $240 \mathrm{~nm}$. The CAT activity was expressed as U.mg ${ }^{-1}$ prot.

The APX activity was assayed according to the method of Nakano and Asada (1981). The $3.0 \mathrm{~mL}$ of reaction mixture contained $2.5 \mathrm{~mL}$ of $50 \mathrm{~mm}$ potassium phosphate reaction buffer $(\mathrm{pH} 7.0)$ containing $0.1 \mathrm{~mm}$ EDTA and $0.5 \mathrm{~mm}$ ascorbic acid, $0.3 \mathrm{~mL}$ of $0.1 \mathrm{mM} \mathrm{H}_{2} \mathrm{O}_{2}$, and $0.2 \mathrm{~mL}$ of enzyme extract. The $\mathrm{H}_{2} \mathrm{O}_{2}$-dependent oxidation of ascorbate was followed by a decrease in the absorbance at $290 \mathrm{~nm}$. One unit of APX activity was defined as the amount of enzyme causing a decrease of 0.01 in absorbance per minute at $290 \mathrm{~nm}$. APX activity was expressed as $\mathrm{U} \cdot \mathrm{mg}^{-1}$ prot.

The activity of GR was determined by using a GR Detection Kit following the manufacturer's instructions (NJBI). A $0.2-\mathrm{mL}$ enzyme extract was quickly mixed with $2.4 \mathrm{~mL}$ of reaction solution, and the absorbance of the mixture was monitored at $340 \mathrm{~nm}$ after $30 \mathrm{~s}$, and then monitored again after the mixture was incubated at $37^{\circ} \mathrm{C}$ for $150 \mathrm{~s}$. One unit of GR activity was defined as the amount of enzyme that caused a $1 \mathrm{~mm}$ change in NADPH (nicotinamide adenine dinucleotide phosphate) per minute at $340 \mathrm{~nm}$. The GR activity was expressed as $\mathrm{U} \cdot \mathrm{mg}^{-1}$ prot.

Determinations of related enzymes in energy metabolism. Mitochondria of mango fruit were isolated as described by Jin et al. (2013). Mesocarp tissue (20.0 g) was homogenized in an ice bath together with $30 \mathrm{~mL}$ of grinding medium using a mortar and pestle. The grinding medium was composed of $50 \mathrm{~mm}$ Tris- $\mathrm{HCl}$ buffer, $\mathrm{pH} 7.5,0.25 \mathrm{M}$ sucrose, $0.3 \mathrm{M}$ mannitol, $1 \mathrm{~mm}$ EDTA, $0.5 \%(\mathrm{w} / \mathrm{v})$ PVPP, $0.1 \%(\mathrm{w} / \mathrm{v})$ bovine serum albumin (BSA), and $0.1 \%(\mathrm{v} / \mathrm{v})$ betamercaptoethanol. The homogenate was squeezed through six layers of cotton gauze and centrifuged at $5000 \times g_{\mathrm{n}}$ for $20 \mathrm{~min}$. The supernatant was centrifuged at $20,000 \times g_{n}$ for $30 \mathrm{~min}$. The precipitate was washed twice with $10 \mathrm{~mL}$ of washing medium and reextracted in the same manner as above. The washing medium was composed of $10 \mathrm{~mm}$ Tris- $\mathrm{HCl}$ buffer, $\mathrm{pH} 7.5$, containing $0.25 \mathrm{M}$ sucrose, $0.3 \mathrm{M}$ mannitol, and $1 \mathrm{~mm}$ EDTA. The final precipitate was suspended in $3.0 \mathrm{~mL}$ of washing medium for the enzyme assays. All steps in the preparation of extract were carried out at $4{ }^{\circ} \mathrm{C}$.

The SDH activity was revealed according to the procedure described by Ackrell et al. (1978) with some modifications. The reaction was carried out at $30^{\circ} \mathrm{C}$ for $5 \mathrm{~min}$ in a $4.5-\mathrm{mL}$ reaction mixture containing $3.0 \mathrm{~mL}$ of $0.2 \mathrm{~mm}$ pH 7.4 phosphate buffer, $1.0 \mathrm{~mL}$ of $0.2 \mathrm{~mm}$ sodium succinate, $0.1 \mathrm{~mL}$ of 0.9 $\mathrm{mmol} \cdot \mathrm{L}^{-1}$ 2, 6-dichlorophenolindophenol, $0.1 \mathrm{~mL}$ of $10 \mathrm{~mm}$ methyl sulfanyl phenazine, 
and $0.3 \mathrm{~mL}$ of crude mitochondrial extract. One unit of SDH activity was defined as the amount of enzyme that caused 0.01 change of absorbance per minute at $600 \mathrm{~nm}$ under the assay conditions. The SDH activity was expressed as U. $\mathrm{mg}^{-1}$ prot.

The CCO activity was determined according to Jin et al. (2013). The reaction was carried out at $37^{\circ} \mathrm{C}$ for $3 \mathrm{~min}$ in an assay medium consisting of $0.2 \mathrm{~mL}$ of $0.3 \mathrm{~mm}$ cytochrome $\mathrm{C}$ solution, $0.5 \mathrm{~mL}$ of $20 \mathrm{mmol} \cdot \mathrm{L}^{-1}$ dimethyl phenylenediamine, $0.2 \mathrm{~mL}$ of crude mitochondria extract, and $2.0 \mathrm{~mL}$ of double distilled water. The oxidizing velocity of reduced cytochrome $\mathrm{C}$ at $510 \mathrm{~nm}$ was determined. One unit of $\mathrm{CCO}$ activity was defined as the amount of enzyme that caused 0.01 absorbance change per minute at $510 \mathrm{~nm}$ under the assay conditions. The $\mathrm{CCO}$ activity was expressed as U.mg ${ }^{-1}$ prot.

Measurements of the activities of $\mathrm{Ca}^{2+}$ ATPase and $\mathrm{H}^{+}$-ATPase were performed according to Jin et al. (2013). The total volume of both reaction mixtures was $3.0 \mathrm{~mL}$. For $\mathrm{Ca}^{2+}$-ATPase, the assay medium consisted of $2.7 \mathrm{~mL}$ of $30 \mathrm{~mm} \mathrm{pH} \mathrm{8.0} \mathrm{Tris-} \mathrm{HCl}$ containing $3 \mathrm{mM} \mathrm{Mg}_{2} \mathrm{SO}_{4}, 0.1 \mathrm{~mm} \mathrm{Na} \mathrm{VO}_{4}, 50 \mathrm{~mm}$ $\mathrm{NaNO}_{3}, 3 \mathrm{~mm} \mathrm{Ca}\left(\mathrm{NO}_{3}\right)_{2}$, and $0.1 \mathrm{~mm}$ ammonium molybdate, combined with $0.3 \mathrm{~mL}$ of mitochondrial extract. For $\mathrm{H}^{+}$-ATPase, the assay medium was $2.7 \mathrm{~mL}$ of $30 \mathrm{~mm} \mathrm{pH} 8.0$ Tris- $\mathrm{HCl}$ containing $3 \mathrm{mM} \mathrm{Mg}_{2} \mathrm{SO}_{4}, 0.1 \mathrm{~mm}$ $\mathrm{Na}_{3} \mathrm{VO}_{4}, 50 \mathrm{~mm} \mathrm{NaNO}_{3}$, and $0.1 \mathrm{~mm}$ ammonium molybdate, combined with $0.3 \mathrm{~mL}$ of mitochondrial extract. For both assays, $100 \mu \mathrm{L}$ of $30 \mathrm{~mm}$ ATP-Tris ( $\mathrm{pH} \mathrm{8.0)}$ was added to initiate the reaction. The mixture was then incubated at $37{ }^{\circ} \mathrm{C}$ for $30 \mathrm{~min}$ followed by addition of $55 \%$ trichloroacetic acid to end the reaction. The amount of inorganic phosphorus was determined by using an "Inorganic Phosphorus Detection Kit" based on the manufacturer's instructions (NJBI). One unit of $\mathrm{Ca}^{2+}$-ATPase and $\mathrm{H}^{+}$-ATPase activities was defined as the amount of enzyme that caused the release of $1 \mu \mathrm{mol}$ of phosphorus in absorbance per minute at $660 \mathrm{~nm}$ under the assay conditions. The activities of $\mathrm{Ca}^{2+}$-ATPase and $\mathrm{H}^{+}$-ATPase were expressed as U. $\mathrm{mg}^{-1}$ prot.

Protein contents were measured according to the method of Bradford (1976) using BSA as standard.

Statistical analysis. All data were expressed as mean values \pm SE, and then were subjected to one-way analysis of variance. Mean separations were performed by Duncan's multiple range tests (SPSS Version 14.0). All differences between treatments and during storage mentioned in this report are significant at $P \leq 0.05$.

\section{Results}

Effect of $O A$ on CI, firmness, and fruit decay. Visible CI symptoms in 'Tommy Atkins' fruit with QHWT were first observed after $9 \mathrm{~d}$ at $5{ }^{\circ} \mathrm{C}$ and were reduced by OA treatment. Symptom development progressed during the remainder of storage. However, after being transferred to $25^{\circ} \mathrm{C}$, external CI development continued to be less severe compared with the control only for the fruit treated with $5 \mathrm{~mm}$ OA (Fig. 1A). Also, in contrast to the control, 'Tommy Atkins' fruit treated with OA retained higher fruit firmness when the fruit were transferred to $25{ }^{\circ} \mathrm{C}$ (Fig. 1B), but exhibited no substantial differences in internal CI symptoms and fruit decay at the end of storage (Fig. 2).

The effects of $5 \mathrm{~mm} \mathrm{OA}$ on external and internal CI symptoms in the 'Zill' fruit used in the present research (Expt. 2) were previously reported (Li et al., 2014). CI symptoms were first observed in both $\mathrm{OA}$ and control fruit after $28 \mathrm{~d}$ in storage at $10{ }^{\circ} \mathrm{C}$, and gradually increased thereafter. However, the external and internal $\mathrm{CI}$ indices for OAtreated fruit were significantly lower than that of control fruit from 35 to $49+4 \mathrm{~d}$ in storage and from 42 to $49+4 \mathrm{~d}$ in storage, respectively. Treatment of 'Zill' with $5 \mathrm{~mm}$ $\mathrm{OA}$ also resulted in significantly greater retention of flesh firmness from 28 to $49 \mathrm{~d}$ compared with the control (Li et al., 2014).

Effect of $O A$ on MDA content and relative leakage rate in 'Zill' fruit. The MDA content in the control and OA-treated 'Zill' fruit increased gradually in $10{ }^{\circ} \mathrm{C}$ storage until $35 \mathrm{~d}$, and then was maintained steady over the remaining days, while relative electrolyte leakage rate in both treatments increased
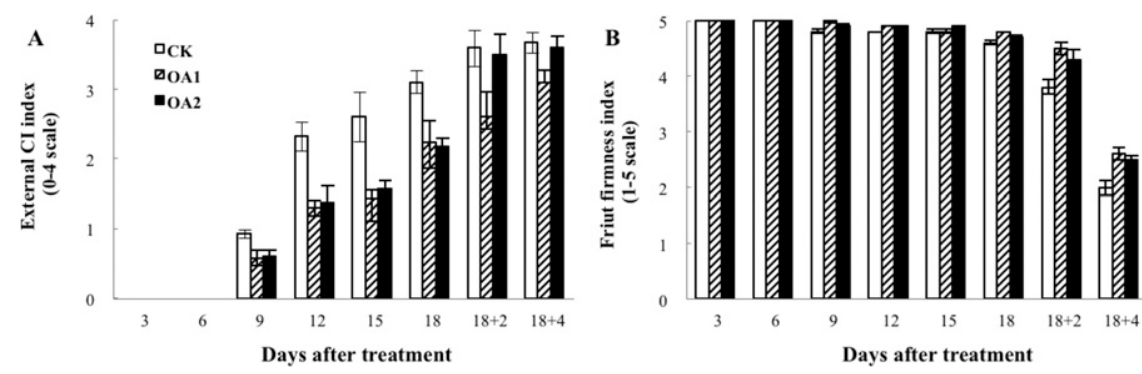

Fig. 1. Effect of oxalic acid (OA) on external chilling injury (CI) symptoms index ( 0 to 4 scale) and fruit firmness index ( 1 to 5 scale) of 'Tommy Atkins' mango fruit that had been treated initially with quarantine hot water treatment (QHWT). The fruit were treated with $0(\mathrm{CK}), 5(\mathrm{OA} 1)$, or $10 \mathrm{~mm}(\mathrm{OA} 2)$ oxalic acid following QHWT; " $18+2$ " and " $18+4$ " means fruit were transferred to $25^{\circ} \mathrm{C}$ and held for 2 or $4 \mathrm{~d}$, respectively, following exposure to a chilling stress of $18 \mathrm{~d}$ at $5{ }^{\circ} \mathrm{C}$. Data were the means of three, 10 -fruit replicates $\pm \mathrm{SE}$.

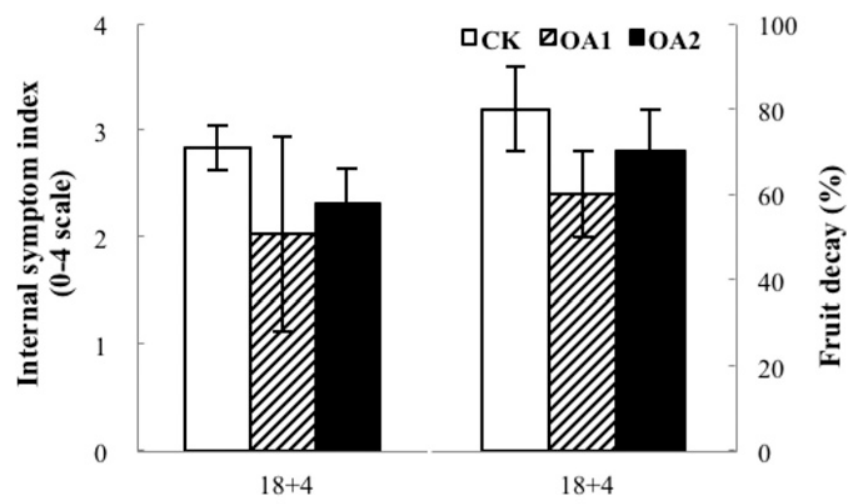

\section{Days after treatment Days after treatment}

Fig. 2. Effect of oxalic acid (OA) on internal chilling injury (CI) symptom index and fruit decay of 'Tommy Atkins' mango fruit that had been treated initially with quarantine hot water treatment following exposure to a chilling stress of $18 \mathrm{~d}$ at $5{ }^{\circ} \mathrm{C}$ plus $4 \mathrm{~d}$ at $25^{\circ} \mathrm{C}$. Symbols for treatments are the same as in Fig. 1. Data were the means of three, 10 -fruit replicates \pm SE. 
gradually over the remaining days of storage, but there was significantly higher SOD activity in the OA-treated fruit from days 14 to 35 compared with the control (Fig. 5A).

The CAT activity in all 'Zill' fruit showed increasing but fluctuating levels during storage, but it was significantly higher in OAtreated fruit than in the control from 35 to $49 \mathrm{~d}$ of storage (Fig. 5B). The CAT activity declined in OA-treated fruit after transfer to $25^{\circ} \mathrm{C}$ for $4 \mathrm{~d}$, but was maintained during the same period in control fruit, resulting in no
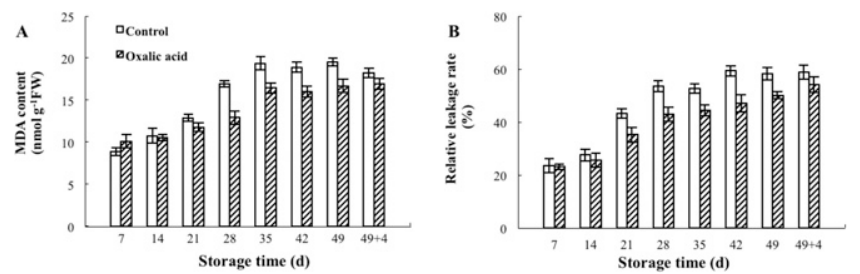

Fig. 3. Effect of oxalic acid (OA) on (A) malondialdehyde (MDA) content and (B) relative electrolyte leakage rate of 'Zill' mango fruit without quarantine hot water treatment during storage at $10^{\circ} \mathrm{C}$. The fruit were treated with 0 (control) or $5 \mathrm{~mm} \mathrm{OA}$; " $49+4$ " means fruit were transferred to $25^{\circ} \mathrm{C}$ and held for $4 \mathrm{~d}$ following exposure to a chilling stress of $49 \mathrm{~d}$ at $10^{\circ} \mathrm{C}$. Data were the means of three, 10 -fruit replicates \pm SE.
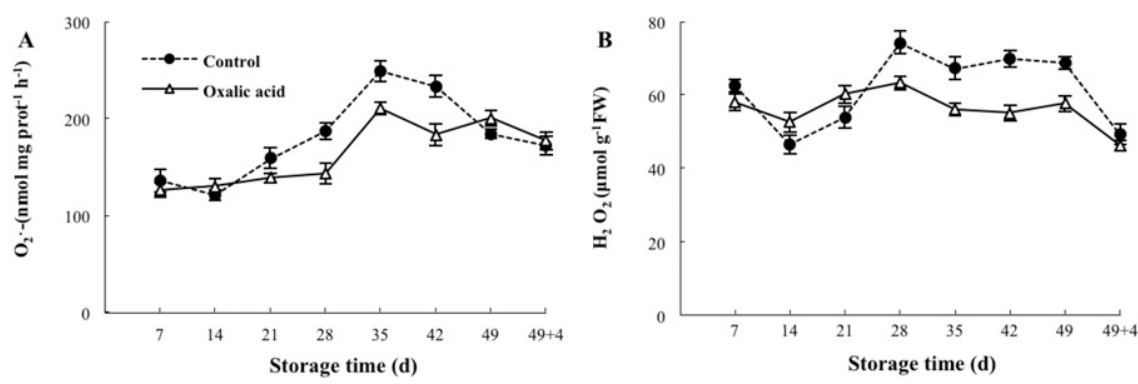

Fig. 4. Effect of oxalic acid (OA) on the rate of $(\mathbf{A})$ superoxide radical $\left(\mathrm{O}_{2}-\cdot\right)$ production and $(\mathbf{B})$ hydrogen peroxide $\left(\mathrm{H}_{2} \mathrm{O}_{2}\right)$ content of ' $\mathrm{Zill}$ ' mango fruit without quarantine hot water treatment during storage at $10{ }^{\circ} \mathrm{C}$. The fruit were treated with 0 (control) or $5 \mathrm{~mm} \mathrm{OA}$; “ $49+4$ " means fruit were transferred to $25^{\circ} \mathrm{C}$ and held for $4 \mathrm{~d}$ following exposure to a chilling stress of $49 \mathrm{~d}$ at $10^{\circ} \mathrm{C}$. Data were the means of three, 10 -fruit replicates \pm SE.
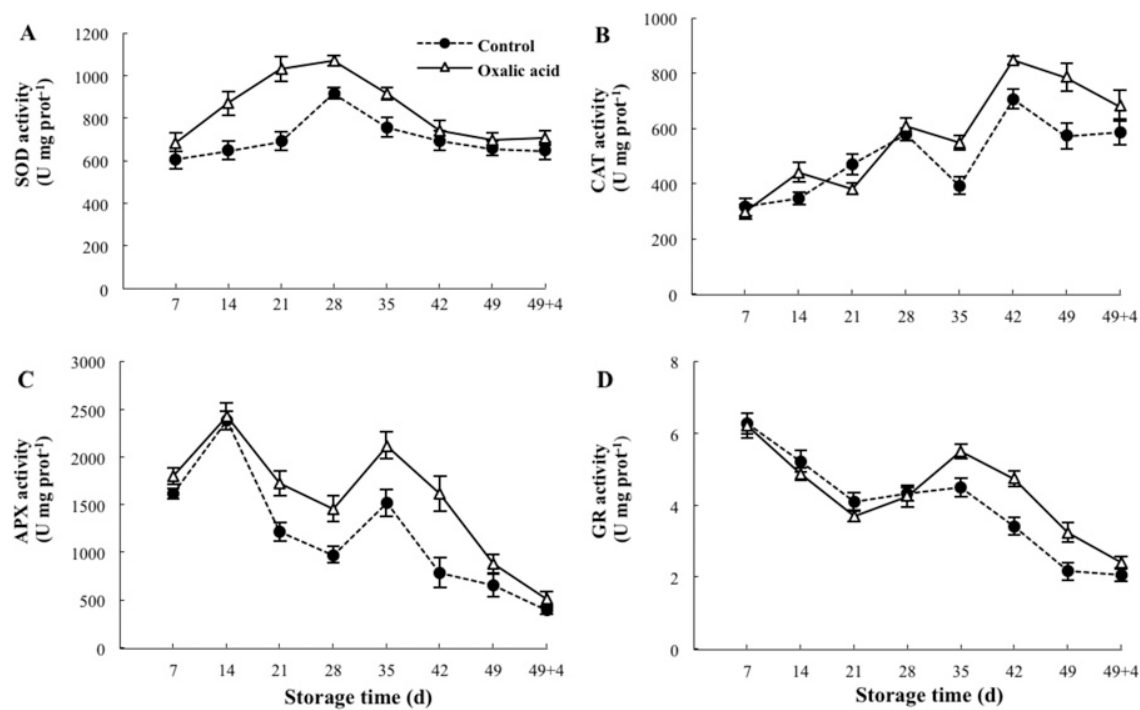

Fig. 5. Effect of oxalic acid (OA) on (A) superoxide dismutase (SOD), (B) catalase (CAT), (C) ascorbate peroxidase (APX), and (D) glutathione reductase (GR) of 'Zill' mango fruit without quarantine hot water treatment during storage at $10{ }^{\circ} \mathrm{C}$. The fruit were treated with 0 (control) or $5 \mathrm{~mm}$ OA; " $49+4$ " means fruit were transferred to $25^{\circ} \mathrm{C}$ and held for $4 \mathrm{~d}$ following exposure to a chilling stress of $49 \mathrm{~d}$ at $10{ }^{\circ} \mathrm{C}$. Data were the means of three, 10 -fruit replicates \pm SE. of the storage period. However, the activity in OA-treated fruit was significant higher than that of the control for storage times longer than $28 \mathrm{~d}$ (Fig. 5D). The GR activity declined further in control fruit after transfer to $25^{\circ} \mathrm{C}$ for $4 \mathrm{~d}$, but was maintained during the same period in OA-treated fruit.

Effect of $\mathrm{OA}$ on activities of SDH, CCO, $\mathrm{Ca}^{2+}$-ATPase, and $\mathrm{H}^{+}$-ATPase in 'Zill' fruit. The SDH activity in the control and OAtreated 'Zill' fruit peaked on the 21 st day and the 28th day, respectively. Thereafter, SDH gradually decreased in OA-treated fruit for the reminder of the experiment, but decreased until day 42 in control fruit before leveling off. However, SDH activity in the OA-treated fruit was maintained higher than that in the control from day 21 to $49+4 \mathrm{~d}$ (Fig. 6A).

The CCO activity decreased throughout storage for both treatments, but at a slower rate in the OA-treated fruit, resulting in maintenance of higher $\mathrm{CCO}$ activity in the OA-treated fruit from day 28 to $49+4 \mathrm{~d}$ (Fig. 6B).

The $\mathrm{Ca}^{2+}$-ATPase activity in the control decreased gradually during storage, whereas, by contrast, in the OA-treated 'Zill' fruit the activity decreased for only the first $14 \mathrm{~d}$, and then increased until $28 \mathrm{~d}$ before gradually declining again, but remaining significantly higher in the OA-treated fruit than in the control from day 28 to $49+4$ d (Fig. 6C).

The pattern of $\mathrm{H}^{+}$-ATPase activity change in control and OA-treated fruit was similar during storage, decreasing for the first $42 \mathrm{~d}$, and then gradually increasing for the remainder of storage. There was no significant difference in $\mathrm{H}^{+}$-ATPase activity between the two treatments during storage (Fig. 6D)

\section{Discussion}

The occurrence and development of CI symptom of mangoes vary for different cultivars, fruit maturities, and the duration and temperature of exposure (Mohammed and Brecht, 2002; Phakawatmongkola et al., 2004). 'Tommy Atkins' fruit with QHWT typically developed external CI symptoms, especially primary discoloration on the surface, rather than flesh browning after the fruit were stored at $5{ }^{\circ} \mathrm{C}$ for $9 \mathrm{~d}$. In our experience, the QHWT does not cause heat injury when applied to mature mango fruit as in the present study (Brecht et al., 2013). Thus, it is clear that the symptoms we observed were in fact due to CI. 'Zill' fruit without QHWT have been found to develop external CI symptoms along with flesh browning after $25 \mathrm{~d}$ at $10{ }^{\circ} \mathrm{C}$ (Li et al., 2014). However, OA treatment significantly reduced CI symptoms in mangoes with or without QHWT, which demonstrates the important role of $\mathrm{OA}$ in enhancing chilling tolerance for mangoes.

Damage of the plasma membrane is the primary reason for $\mathrm{CI}$ in fruit during cold storage, as the membrane damage sets off a cascade of secondary reactions including 

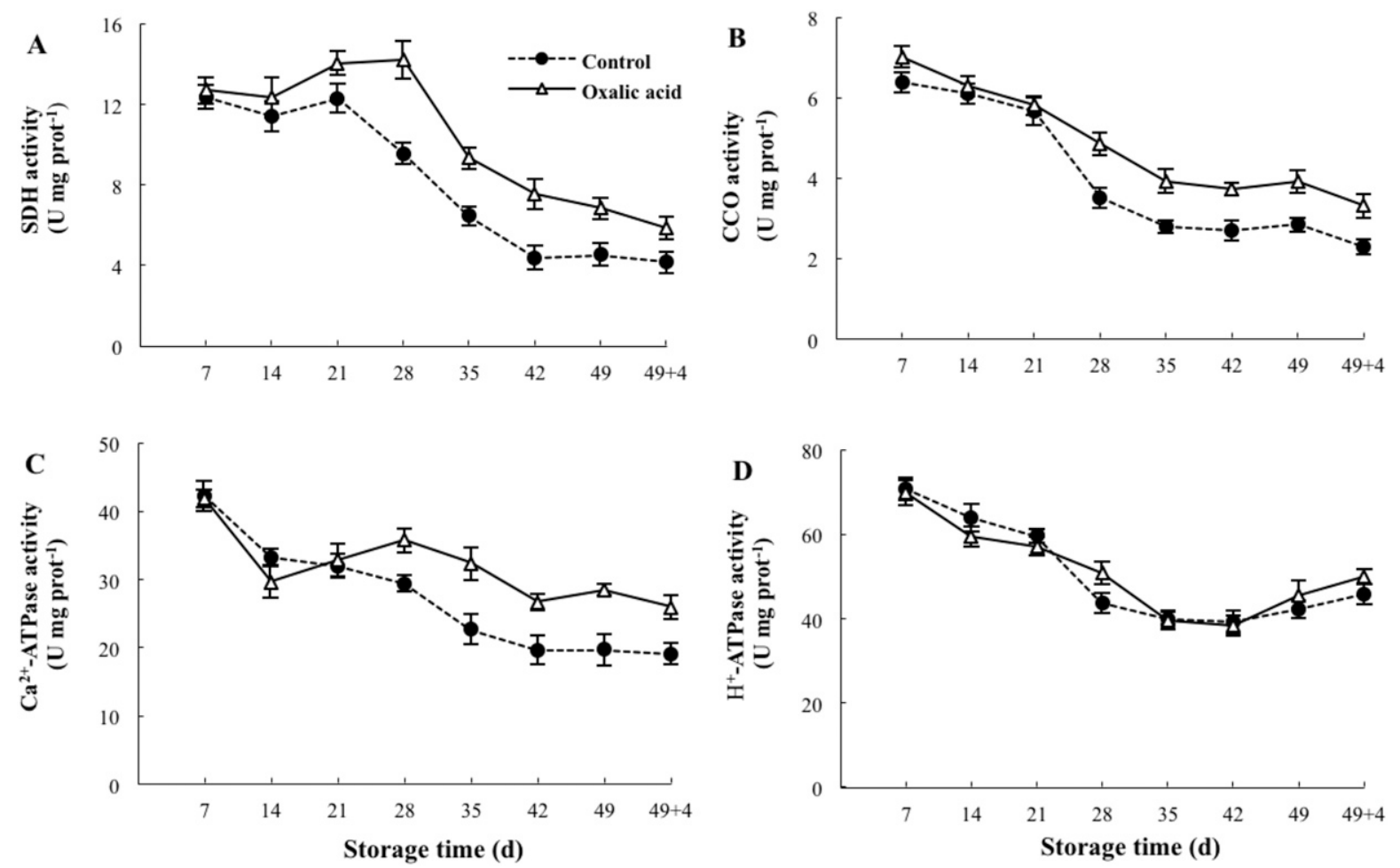

Fig. 6. Effect of oxalic acid (OA) on (A) succinate dehydrogenase (SDH), (B) cytochrome C oxidase (CCO), (C) $\mathrm{Ca}^{2+}$-adenosine triphosphatase $\left(\mathrm{Ca}^{2+}\right.$-ATPase), and $($ D $) \mathrm{H}^{+}$-adenosine triphosphatase $\left(\mathrm{H}^{+}\right.$-ATPase) of 'Zill' mango fruit without quarantine hot water treatment during storage at $10^{\circ} \mathrm{C}$. The fruit were treated with 0 (control) or $5 \mathrm{~mm} \mathrm{OA}$; " $49+4 \mathrm{~d}$ " means fruit were at $25^{\circ} \mathrm{C}$ for $4 \mathrm{~d}$ following exposure to chilling stress at $10^{\circ} \mathrm{C}$ for $49 \mathrm{~d}$. Data were the means of three, 10 -fruit replicates $\pm \mathrm{SE}$.

increased respiration, ethylene production, and enzymatic browning, as well as accumulation of toxic compounds and altered cellular structure (Rui et al., 2010). Salicylic acid, methyl jasmonate, or nitric oxide treatments also alleviate CI in mangoes and such treatments are associated with decreased lipid peroxidation of cell membranes and maintenance of membrane integrity during cold storage and subsequent ripening at room temperature (Ding et al., 2007; González-Aguilar et al., 2001; Zaharah and Singh, 2011). Our previous studies have revealed that OA contributes to maintaining membrane integrity in litchi fruit (Zheng and Tian, 2006), peach fruit (Zheng et al., 2007b), as well as in mango fruit (Zheng et al., 2007a) during storage at low temperature. Prespraying OA also alleviates membrane damage in pepper leaves under heat stress (Zhang et al., 2001). In this study, MDA content (a product of membrane peroxidation) and electrolytic leakage in the flesh of 'Zill' mangoes rapidly increased after $21 \mathrm{~d}$ at $10^{\circ} \mathrm{C}$, but in OA-treated fruit MDA significantly decreased in contrast to the control, which shows the benefit of OA in maintaining membrane integrity, and in turn contributing to resistance to CI development of mango fruit during long-term storage at lower temperatures and after subsequent transfer to room temperature.

It has also been thought that chilling temperature during storage induces oxidative stress through accumulation of reactive oxygen species (ROS), which results in membrane damage and consequently $\mathrm{CI}$ in fruit (Ding et al., 2007; Wang, 1993). The ROS can be scavenged by both nonenzymatic antioxidants and by an enzymatic system comprising enzymes, such as SOD, CAT, APX, and GR (Mittler, 2002). Prestorage application of some chemicals such as methyl jasmonate and 6-benzylaminopurine alleviates $\mathrm{CI}$ in fruit during cold storage and such treatments are associated with increases in those enzymatic activities that reduce ROS accumulation (Cai et al., 2011; Chen and Yang, 2013). Our present results also show that OA treatment significantly enhances the activities of SOD, CAT, APX, and GR in chilled 'Zill' fruit, with accompanying lower levels of $\mathrm{H}_{2} \mathrm{O}_{2}$ and $\mathrm{O}_{2}-$, which could protect membranes from oxidative stress and subsequently contribute to decreased CI development during storage at low temperature.

Energy status is associated with ripening, senescence, and physiological disorders in harvested fruit (Jiang et al., 2007). Increasing evidence has shown that CI development in several types of fruits is partly attributed to limited availability of energy or low energy production, whereas maintaining higher ATP levels and higher energy charge alleviates CI (Chen and Yang, 2013; Jin et al., 2014; Li et al., 2014). Moreover, SDH, $\mathrm{CCO}, \mathrm{Ca}^{2+}$ ATPase, and $\mathrm{H}^{+}$-ATPase are important enzymes involved in oxidative phosphorylation and ATP production. Methyl jasmonate treatment increases the activities of $\mathrm{SDH}, \mathrm{CCO}$, $\mathrm{Ca}^{2+}$-ATPase, and $\mathrm{H}^{+}$-ATPase and is associated with chilling tolerance of peach fruit during storage at low temperatures (Jin et al., 2013). Zhao et al. (2012) have also reported that low temperature conditioning regulates the activities of these enzymes, thereby maintaining higher energy status, delaying membrane lipid peroxidation, and preventing development of CI in cold-stored peach fruit. Our previous report has shown that OA treatment increases the ATP content and energy charge in 'Zill' mango fruit during storage at $10^{\circ} \mathrm{C}$ (Li et al., 2014). In this study, 'Zill' fruit treated with OA maintained higher activities of $\mathrm{SDH}, \mathrm{CCO}, \mathrm{H}^{+}$-ATPase, and $\mathrm{Ca}^{2+}$-ATPase compared with the control. Such effects of OA revealed here are consistent with the previous study in peach fruit by Jin et al. (2014). Therefore, these facts together with the evidence in previous works suggest that the effect of $\mathrm{OA}$ in regulating energy metabolism in mango fruit, especially improving the efficiency of the citric acid cycle and electron transport chain to maintain higher energy status, might possibly contribute to enhancing chilling tolerance during cold storage.

In conclusion, OA might enhance $\mathrm{CI}$ tolerance in mango fruit by maintaining membrane integrity associated with enhanced antioxidant activity and regulation of energy metabolism. Application of $5 \mathrm{~mm}$ $\mathrm{OA}$ to harvested fruit before low-temperature storage appears to be beneficial in controlling postharvest $\mathrm{CI}$ in mangoes. 


\section{Literature Cited}

Ackrell, B.A., E.B. Keamery, and T.P. Singer. 1978. Mammalian succinate dehydrogenase. Methods Enzymol. 53:466-483.

Anwar, R. and A.U. Malik. 2007. Hot water treatment affects ripening quality and storage life of mango (Mangifera indica L.). Pakistan J. Agr. Sci. 44:304-311.

Beers, R.F. and I.W. Sizer. 1952. A spectrophotometric method for measuring the breakdown of hydrogen peroxide by catalase. J. Biol. Chem. 95:133-140.

Bradford, M.M. 1976. A rapid and sensitive method for the quantitation of microgram quantities of protein utilizing the principledye binding. Anal. Biochem. 72:248-254.

Brecht, J.K., S.A. Sargent, A.A. Kader, E.A Mitcham, F. Maul, P.E. Brecht, and O. Menocal. 2013 (revised). Mango postharvest best management practices manual. J.K. Brecht (ed.) HS1185. National Mango Board and UF/IFAS, Gainesville, FL.

Cai, Y.T., S.F. Cao, Z.F. Yang, and Y.H. Zheng. 2011. MeJA regulates enzymes involved in ascorbic acid and glutathione metabolism and improves chilling tolerance in loquat fruit. Postharvest Biol. Technol. 59:324-326.

Chen, B.X. and Q.H. Yang. 2013. 6-Benzylaminopurine alleviates chilling injury of postharvest cucumber fruit through modulating antioxidant system and energy status. J. Sci. Food Agr. 93:1915-1921.

Ding, Z.S., S.P. Tian, X.L. Zheng, Z.W. Zhou, and Y. Xu. 2007. Responses of reactive oxygen metabolism and quality in mango fruit to exogenous oxalic acid or salicylic acid under chilling temperature stress. Physiol. Plant. 130:112-121.

González-Aguilar, G.A., J.G. Buta, and C.Y Wang. 2001. Methyl jasmonate reduces chilling injury symptoms and enhances colour development of 'Kent' mangoes. J. Sci. Food Agr. 81:1244-1249.

Hodges, D.M., J.M. Delong, C. Forney, and R.K. Prange. 1999. Improving the thiobarbituric acid-reactive-substances assay for estimating lipid peroxidation in plant tissue containing anthocyanin and other interfering compounds. Planta 207:604-611.

Jiang, Y.M., Y.L. Jiang, H.X. Qu, X.W. Duan, Y.B. Luo, and W.B. Jiang. 2007. Energy aspects in ripening and senescence of harvested horticultural crops. Stewart Postharv. Rev. 2:1-5.

Jin, P., H. Zhu, J. Wang, J.J. Chen, X.L. Wang, and Y.H. Zheng. 2013. Effect of methyl jasmonate on energy metabolism in peach fruit during chilling stress. J. Sci. Food Agr. 93:1827-1832.

Jin, P., H. Zhu, L. Wang, T. Shan, and Y.H. Zheng. 2014. Oxalic acid alleviates chilling injury in peach fruit by regulating energy metabolism and fatty acid contents. Food Chem. 161:87-93.

Junmatong, C., J. Uthaibutra, D. Boonyakiat, B. Faiyue, and K. Saengnil. 2012. Reduction of chilling injury of 'Nam Dok Mai No. 4' mango fruit by treatments with salicylic acid and methyl jasmonate. J. Agric. Sci. 4:126-136.

Kim, Y., J.K. Brecht, and S.T. Talcott. 2007. Antioxidant phytochemical and fruit quality changes in mango (Mangifera indica L.) following hot water immersion and controlled atmosphere storage. Food Chem. 105:13271334.

Kim, Y., A.J. Lounds-Singleton, and S.T. Talcott 2009. Antioxidant phytochemical and quality changes associated with hot water immersion treatment of mangoes (Mangifera indica L.). Food Chem. 115:989-993.

Li, P.Y., X.L. Zheng, Y. Liu, and Y.Y. Zhu. 2014 Pre-storage application of oxalic acid alleviates chilling injury in mango fruit by modulating proline metabolism and energy status under chilling stress. Food Chem. 142:72-78

Madamanchi, N.R. and R.G. Alscher. 1991. Metabolic bases for differences in sensitivity of two pea cultivars to sulfur dioxide. Plant Physiol. 97:88-93.

Mittler, R. 2002. Oxidative stress, antioxidants and stress tolerance. Trends Plant Sci. 7:405410.

Mohammed, M. and J.K. Brecht. 2002. Reduction of chilling injury in 'Tommy Atkins' mangoes during ripening. Sci. Hort. 95:297-308.

Nair, S., Z. Singh, and S.C. Tan. 2001. Heat treatments affect development of chilling injury, respiration, ethylene production and fruit quality of mango. Acta Hort. 553:549-550.

Nakano, Y. and K. Asada. 1981. Hydrogen peroxide is scavenged by ascorbate specific peroxidase in spinach chloroplast. Plant Cell Physiol. 22:867-880

Nunes, M.C.N., J.P. Émond, J.K. Brecht, S. Dea, and E. Proulx. 2007. Quality curves for mango fruit (cv. Tommy Atkins and Palmer) stored at chilling and nonchilling temperatures. J. Food Qual. 30:104-120.

Phakawatmongkola, W., S. Ketsa, and W.G.V. Doorn. 2004. Variation in fruit chilling injury among mango cultivars. Postharvest Biol Technol. 32:115-118.

Rui, H.J., S.F. Cao, H.T. Shang, P. Jin, K.T. Wang, and Y.H. Zheng. 2010. Effects of heat treatment on internal browning and membrane fatty acid in loquat fruit in response to chilling stress. J. Sci. Food Agr. 90:1557-1561.

Ruíz-Jiménez, J.M., P.J. Zapata, M. Serrano, D Valero, D. Martínez-Romero, S. Castillo, and F. Fabián Guillén. 2014. Effect of oxalic acid on quality attributes of artichokes stored at ambient temperature. Postharvest Biol. Technol. 95:60-63.

Sayyari, M., D. Valero, M. Babalar, S. Kalantari, P.J. Zapata, and M. Serrano. 2010. Prestorage oxalic acid treatment maintained visual quality, bioactive compounds, and antioxidant potential of pomegranate after long-term storage at $2{ }^{\circ} \mathrm{C}$. J. Agr. Food Chem. 58:6804-6808.
USDA-APHIS. 2014. Plant protection and quarantine treatment manual. Schedule T102-a, p. 5-2-58-5-2-60.

Valero, D., H.M. Díaz-Mula, P.J. Zapata, F. Castillo, S. Guillenì, D. Martínez-Romero, and M. Serrano. 2011. Postharvest treatments with salicylic acid, acetylsalicylic acid or oxalic acid delayed ripening and enhanced bioactive compounds and antioxidant capacity in sweet cherry. J. Agr. Food Chem. 59:5483-5489.

Wang, A.G. and G.H. Lou. 1990. Quantitative relation between the reaction of hydroxylamine and superoxide anion radicals in plants. Plant Physiol. Commun. 6:55-57.

Wang, B.G., J.H. Wang, H. Liang, J.Y. Yi, J.J. Zhang, L. Lin, Y. Wu, X.Y. Feng, J.K. Cao, and W.B. Jiang. 2008. Reduced chilling injury in mango fruit by 2,4-dichlorophenoxyacetic acid and the antioxidant response. Postharvest Biol. Technol. 48:172-181.

Wang, C.Y. 1993. Approaches to reduce chilling injury of fruits and vegetables. Hort. Rev. 15:63-95.

Yoruk, R., S. Yoruk, M.O. Balaban, and M.R. Marshall. 2004. Machine vision analysis of antibrowning potency for oxalic acid: A comparative investigation on banana and apple. J. Food Sci. 69:282-289.

Zaharah, S.S. and Z. Singh. 2011. Postharvest nitric oxide fumigation alleviates chilling injury, delays fruit ripening and maintains quality in cold-stored 'Kensington Pride' mango. Postharvest Biol. Technol. 60:202-210.

Zhang, Z.S., R.Q. Li, and J.B. Wang. 2001. Effects of oxalate treatment on the membrane permeability and calcium distribution in pepper leaves under heat stress. Acta Phytophysiol. Sin. 27:109-113.

Zhao, Y.Y., J.J. Chen, P. Jin, R.X. Yuan, H.H. Li, and Y.H. Zheng. 2012. Effects of low temperature conditioning on chilling injury and energy status in cold-stored peach fruit. Food Sci. 33:276-281

Zheng, X.L., G.X. Jing, Y. Liu, T.J. Jiang, Y.M. Jiang, and J.R. Li. 2012. Expression of expansin gene, MiExpA1, and activity of galactosidase and polygalacturonase in mango fruit as affected by oxalic acid during storage at room temperature. Food Chem. 132: 849-854.

Zheng, X.L. and S.P. Tian. 2006. Effect of oxalic acid on control of postharvest browning of litchi fruit. Food Chem. 96:519-523.

Zheng, X.L., S.P. Tian, M.J. Gidley, H. Yue, B.Q. Li, Y. Xu, and Z.W. Zhou. 2007a. Slowing the deterioration of mango fruit during cold storage by pre-storage application of oxalic acid. J. Hort. Sci. Biotechnol. 82:707-714.

Zheng, X.L., S.P. Tian, X.H. Meng, and B.Q. Li. 2007b. Physiological and biochemical responses in peach fruit to oxalic acid treatment during storage at room temperature. Food Chem. 104:156-162. 